\title{
The expression of hDlg as a biomarker of the outcome in malignant fibrous histiocytomas
}

\author{
RUI NIIMI $^{1}$, AKIHIKO MATSUMINE ${ }^{1}$, TAKAHIRO IINO ${ }^{1}$, TETSUYA MURATA ${ }^{2}$, \\ KEN SHINTANI ${ }^{1}$, SHIGETO NAKAZORA ${ }^{1}$, TOMOKI NAKAMURA ${ }^{1}$, YUDAI UEHARA ${ }^{1}$, \\ KATSUYUKI KUSUZAKI $^{3}$, TETSU AKIYAMA ${ }^{4}$ and ATSUMASA UCHIDA ${ }^{1}$
}

\begin{abstract}
${ }^{1}$ Department of Orthopaedic Surgery, Mie University Graduate School of Medicine, 2-174 Edobashi, Tsu city, Mie 514-8507; ${ }^{2}$ Department of Pathology JA Suzuka General Hospital, 1275-53 Yasuzuka Yamanohana, Suzuka, Mie 513-8630; ${ }^{3}$ Department of Orthopaedic Surgery, Oodai Kousei Hospital, 63-8 Oodai Sahara, Taki, Mie 519-2404; ${ }^{4}$ Laboratory of Molecular and Genetic Information, Institute for Molecular and Cellular Biosciences, The University of Tokyo, 1-1-1 Yayoi, Bunkyo-ku, Tokyo 113-0032, Japan
\end{abstract}

Received July 16, 2009; Accepted October 5, 2009

DOI: $10.3892 /$ or_00000678

\begin{abstract}
The human homologue of Drosophila disc large tumor suppressor protein $(\mathrm{hDlg})$ is one of the proteins known to act cooperatively in regulating cell polarity and proliferation, suggesting an important connection between epithelial organization and cellular growth control. An abnormal expression of hDlg has been reported in several cancer types. However, the expression of hDlg in soft-tissue sarcomas has not yet been reported. We examined the expression of $\mathrm{hDlg}$ immunohistochemically in 46 specimens of malignant fibrous histiocytoma (MFH). The expression of hDlg was negative in 19 specimens, weak in 4 , moderate in 16 , and strong in 7 . The patients with a weak or negative expression of hDlg had a significantly shorter metastasis-free survival rate and disease-free survival rate in comparison with those with a strong or moderate expression in both univariate analysis ( $\mathrm{p}=0.0287$ and 0.0237 , respectively; log-rank test) and multivariate analysis $(\mathrm{p}=0.0087$ and 0.0126 , respectively; Cox proportional hazards regression model). Moreover, the patients with a weak or negative expression of hDlg had a significantly shorter overall survival rate in comparison with those with a strong or moderate expression in a univariate analysis $(\mathrm{p}=0.0214$; log-rank test). This is the first report to demonstrate that a reduced expression of hDlg protein is an independent negative prognostic factor for MFH.
\end{abstract}

Correspondence to: Dr Akihiko Matsumine, Department of Orthopaedic Surgery, Mie University Graduate School of Medicine, 2-174 Edobashi, Tsu City, Mie 514-8507, Japan

E-mail: matsumin@clin.medic.mie-u.co.jp

Key words: hDlg, tumor suppressor gene, malignant fibrous histiocytoma, biomarker, prognosis

\section{Introduction}

The Discs large (Dlg) gene was isolated as a Drosophila tumor suppressor gene $(1,2)$. Drosophila Dlg and its mammalian homolog 'hDlg' (Sinapse-Associated Protein 97 kDa; SAP97) belong to the membrane-associated guanylate kinase (MAGUK) family of proteins and bear characteristic structural domains including 3 PDZ domains, an SH3 domain, and a guanylate kinase-like (GUK) region (3). All of these domains are involved in protein-protein interactions which allow the MAGUK proteins to act as intracellular scaffolding molecules in the formation of macromolecular signaling complexes (4-7). The PDZ domains are found in a variety of proteins in single or multiple copies (8). The MAGUK PDZ domains bind and mediate the clustering of the membrane receptors and the channel proteins (9). The $\mathrm{SH} 3$ domain is a well characterized protein-binding domain that is found in a variety of proteins, and it binds to proline-rich motifs, which may allow hDlg to participate in signaling pathways by forming complexes via the $\mathrm{SH} 3$ domains of other proteins (10). Due to sequence divergence, the GUK domain of the MAGUKs shows low or no kinase activity and appears to also act as a protein binding domain (11-14). MAGUKs are known to localize at the regions of cell-to-cell contacts and at the pre-synaptic and post-synaptic density, where they are thought to play an important role in the regulation of cell proliferation and synaptic transmission (8). In addition, hDlg interacts, via its PDZ domain, with the tumor suppressor adenomatous polyposis coli (APC) (15) and with several viral oncoproteins $(16,17)$, thus suggesting that $\mathrm{hDlg}$ is involved in cell growth regulation and tumorigenesis. Indeed, the overexpression of hDlg suppresses cell proliferation by blocking cell cycle progression from the $\mathrm{G} 0 / \mathrm{G} 1$ phase to the $\mathrm{S}$ phase (18).

Epithelial cells display an apico-basal polarity that is required for their correct function. The polarity is mediated by the presence of different cell junctions that depend on the formation of multiprotein networks at the cell membrane (19). Therefore, hDlg is involved in cell growth control, in the 
maintenance of cell adhesion and polarity, and in functions that block cell invasion during development $(1,2,19)$. Therefore, the loss of hDlg may explain some of the characteristics of the malignant cells, such as abnormality of the polarity and the high migration ability which is one of the hallmarks of malignant tumors $(20,21)$. Indeed, the abnormality of the expression of hDlg has been reported in several cancers $(16,22,24,25)$. Previous reports have demonstrated the potential importance of $\mathrm{hDlg}$ in cancer suppression in the cervix $(16,22,23)$, in gastric cancers $(24)$, and in ductal carcinomas (26). Cavatorta et al described that the loss of Dlg may be considered as a late stage marker in the cervical carcinogenic process, although alterations of the level of expression and the intracellular localization of $\mathrm{hDlg}$ take place during the different dysplastic stages (22). However, the expression of $\mathrm{hDlg}$ in soft-tissue sarcomas has not been reported. In this study, we examined the expression of $\mathrm{hDlg}$ in malignant fibrous histiocytoma (MFH).

MFH is characteristically a tumor of late adult life, with most cases occurring in persons between the age of 50 and 70 years. The tumor occurs most frequently on the lower extremities, especially the thigh, followed by the upper extremity and the retroperitoneum. The vast majority of MFH are high-grade lesions. Despite the recent adequate treatment for $\mathrm{MFH}$, the prognosis is still poor. The 5-year local recurrence-free survival (LRFS), the metastasis-free survival (MFS), and the overall survival rate (OS) were reported as $63-87 \%, 62-63 \%$ and 50-74\%, respectively (26-30). Therefore, a biomarker which can predict the high-risk patients is very important because it may be a useful indicator for determining whether adjuvant therapeutic modalities, such as irradiation and chemotherapy, should be performed. The aim of this study was to investigate whether the hDlg protein expression had a prognostic impact on MFH.

\section{Materials and methods}

Study population and tissue preparation. The tissue specimens used for this study were obtained from the patients who underwent surgical resection or an open biopsy at the Department of Orthopaedic Surgery, Mie University Graduate School of Medicine after obtaining informed consent according to the institutional review board guidelines. Immediately after surgical removal, the tissue specimens were fixed in $10 \%$ buffer formalin solution for $24 \mathrm{~h}$ and embedded in paraffin for the histological analysis. The paraffin-embedded tumor tissue specimens, measuring $4 \mu \mathrm{m}$ in thickness, were placed on silanized slides (Matsunami Japan, Osaka, Japan) and stained with hematoxylin and eosin. The histological sections of all the patients were diagnosed by well-trained pathologists.

In all the cases, immunohistochemical staining was used to diagnose MFHs according to the World Health Organization classification (31). MFH was diagnosed primarily based on the morphological appearance of the results which showed no reactivity for immunostaining, and the fact that a storiformpleomorphic type was observed in 46 patients.

In this study, we excluded the patients who had distant metastases at initial treatment, or the patients who had recurrent sarcomas after inadequate treatments at the initial hospital.
Table I. Details of patient characteristics.

\begin{tabular}{lc}
\hline Characteristics & No. (n=46) \\
\hline Gender & 22 \\
Male & 24 \\
Female & \\
Age (years) & 14 \\
$\quad 59$ & 32 \\
$\geq 60$ & \\
Location & 7 \\
Upper extremities & 27 \\
Lower extremities & 12 \\
Trunk & \\
Size (cm) & 10 \\
$<5$ & 36 \\
$\geq 5$ & \\
Depth & 10 \\
Superficial & 36 \\
Deep & \\
Primary or recurrence & \\
Primary & \\
Recurrence & \\
\hline
\end{tabular}

Clinical and pathologic analysis. The details of the clinicopathologic features are listed in Table I. The study comprised 46 patients ( 22 males and 24 females). The median age of all the patients was 66 years (range, $42-86$ years). The median follow-up for all the patients was 50 months (range, 2-145 months). All the patients underwent a complete tumor resection with a wide margin during the initial surgery at our hospital. The 46 samples consisted of 37 primary lesions and 9 local recurrences.

At the final follow-up, 18 patients were continuously disease-free, 11 patients showed no evidence of disease, 5 patients were alive with disease, 11 patients died of disease, and 1 patient died of an unrelated cause.

Immunohistochemical analysis. The paraffin-embedded tumor tissue specimens measuring $4 \mu \mathrm{m}$ in thickness were placed on silanized slides (Matsunami Japan) and then deparaffinized in xylol. Antigen retrieval was performed with $0.01 \mathrm{M}$ citrate buffer at $121^{\circ} \mathrm{C}$ for $10 \mathrm{~min}$, cooling for $60 \mathrm{~min}$ and washing in PBS. The mouse monoclonal anti-SAP97 antibody (clone 2D11, Santa Cruz Biotechnology, Santa Cruz, CA, USA) was diluted 1:50 in the antibody diluent buffer (1\% BSA/PBS). Immunohistochemistry was achieved with the Ventana EX system using a DAB universal kit (iview DAB; Ventana Medical Systems, Tucson, AZ, USA), in which the visualization of the bound antibodies was performed using the streptavidin-biotinylated complex method.

In this study, the expression of $\mathrm{hDlg}$ was assessed semiquantitatively by the following two parameters: the percentage 
A

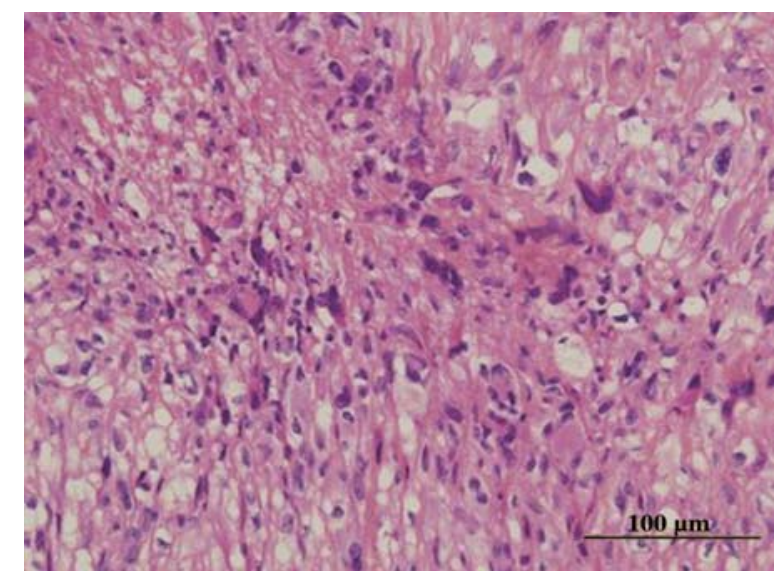

C

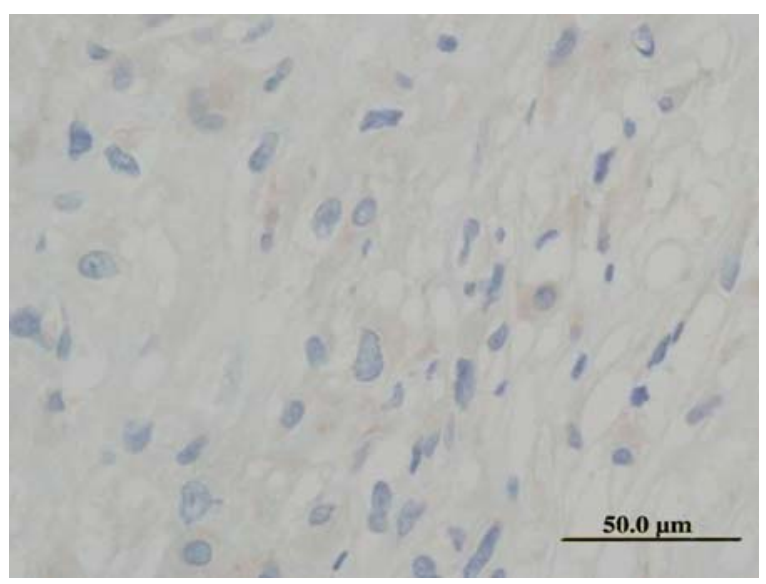

$\mathbf{E}$

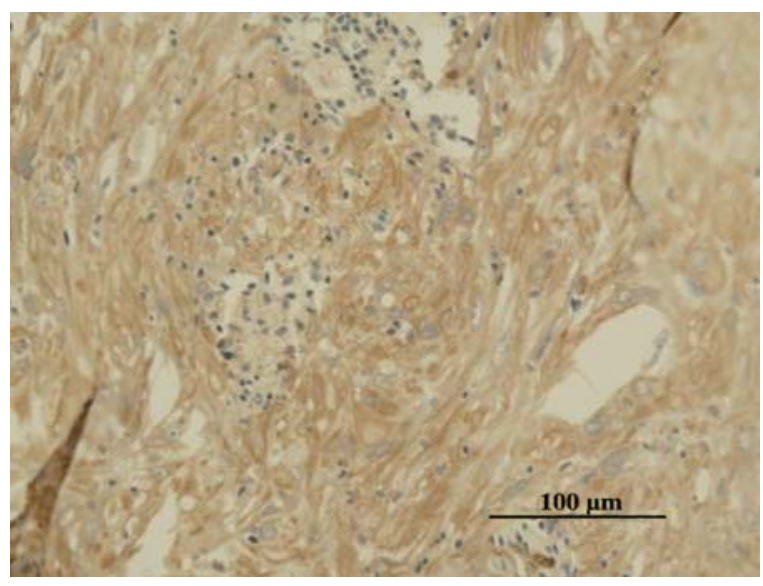

B

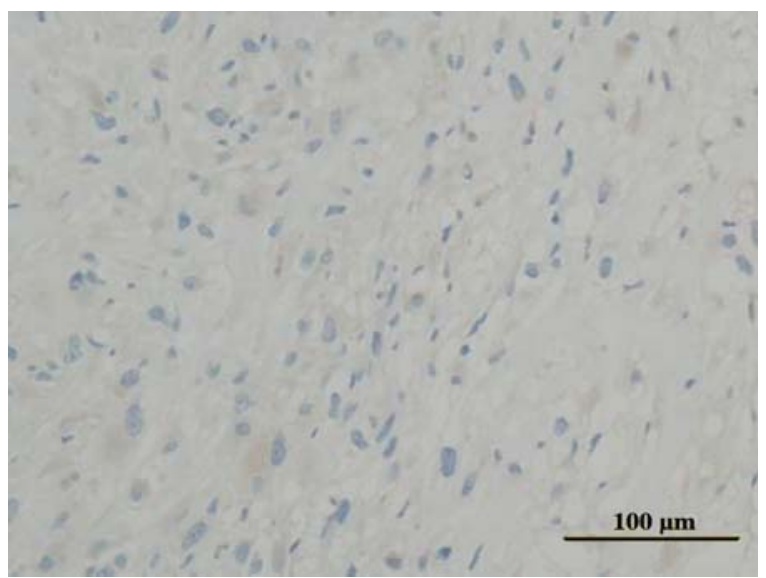

D

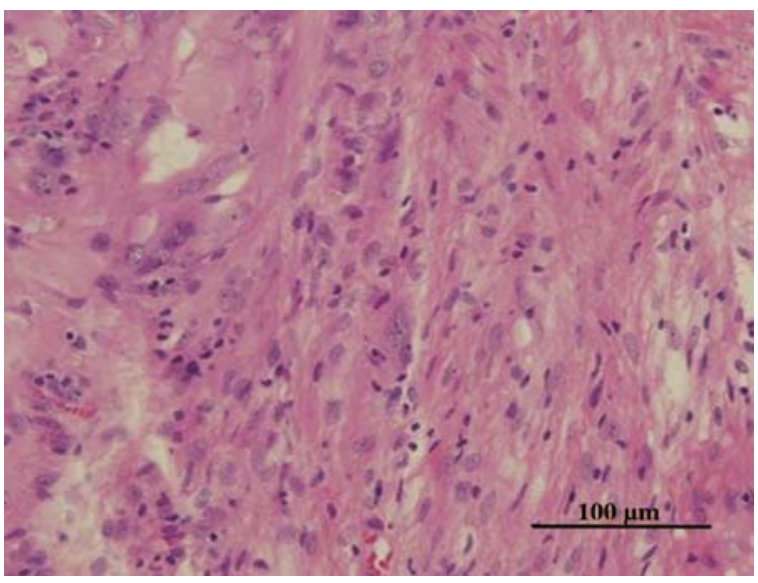

$\mathbf{F}$

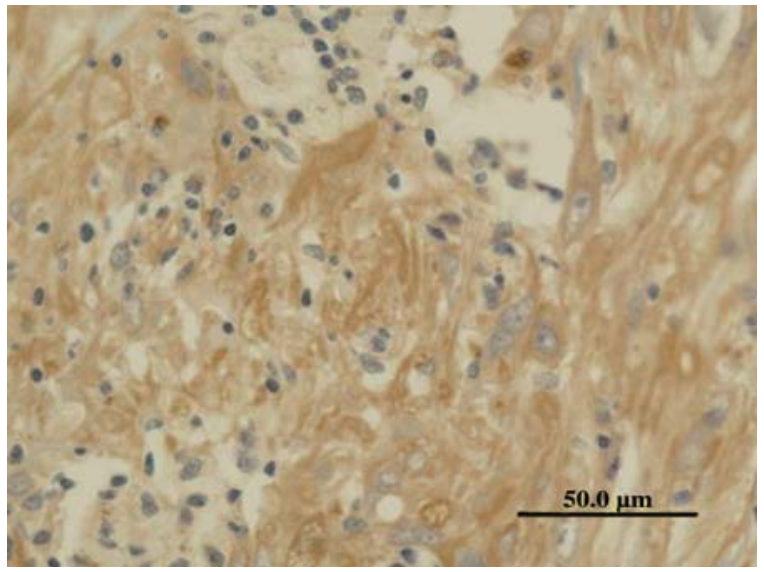

Figure 1. Specimens from a 79-year-old female with malignant fibous histiocytoma [(A) H\&E, x200] showing a weak expression of hDlg [(B) and (C) immunostain; (B) x200, (C) x400]. (D-F) Specimens from a 74-year-old male with malignant fibous histiocytoma [(D) H\&E, x200] showing a strong expression of $\mathrm{hDlg}[(\mathrm{E})$ and $(\mathrm{F})$, immunostain; (E) x200, (F) x400].

of stained tumor cells; and the staining intensity, as referred to the in previous reports (32-34). The percentage of positive cells was rated as follows: 0 point, cases with $10 \%$ positive cells (rated as negative, regardless of staining intensity); 2 points, $11-50 \%$ positive cells; 3 points, $51-80 \%$ positive cells; and 4 points, $>80 \%$ positive cells. The staining intensity was rated as: 1 point, weak intensity; 2 points, moderate intensity; and 3 points, strong intensity. The points for the percentage of positive cells and the staining intensity were added, and the specimens were categorized into four groups according to their overall score; negative expression, $10 \%$ cells stained positive, regardless of intensity, 0-2 points; weak expression, 3 points; moderate expression, 4-5 points; and strong expression, 6-7 points (Fig. 1).

Statistics and analysis. Fisher's exact test and the $\chi^{2}$ test were used to analyze the associations between the clinicalpathological variables. The local recurrence-free survival 
(LRFS) was defined as the time from the initial treatment to the date of the clinically documented local recurrence. The metastasis-free survival (MFS) was defined as the time from the initial treatment to the date of clinically documented distant metastasis. The disease-free survival (DFS) was defined as the time from the initial treatment to the date of clinically documented local recurrence or distant metastasis. The overall survival (OS) was defined as the time from the initial treatment to the date of death attributed to MFH. For a prognostic analysis, the Kaplan-Meier survival analysis and log-rank tests were performed. For a multivariate analysis, a Cox proportional hazards regression model was used to identify the statistically significant differences in the survival and estimate hazard ratios and $95 \%$ confidence intervals. Seven prognostic variables including the patient's age, gender, tumor size, tumor depth, primary tumor or recurrent tumor, location (trunk or extremity), and the expression of hDlg were entered into a Cox multivariate analysis model. A pvalue $<0.05$ was considered to be significant. The analysis was performed using the StatView statistical software package (version 5.0; SAS Institute, Cary, NC, USA).

\section{Results}

Expression of $h D l g$ and associations between hDlg expression and clinico-pathological variables. The staining of $\mathrm{hDlg}$ was observed only in the cytoplasmic area of the sarcoma cells without staining of surrounding myofibroblastic cells. The expression of hDlg was negative in 19 (41.3\%) specimens, weak in $4(8.7 \%)$, moderate in $16(34.8 \%)$, and strong in $7(15.2 \%)$. Fisher's exact test was used to analyze the associations between the hDlg expression and the clinicopathologic variables. The level of $\mathrm{hDlg}$ expression was not associated with patient's age, gender, tumor size, and tumor depth (data not shown; the $\chi^{2}$ test).

Prognostic analysis. We next compared the LRFS, MFS, DFS and OS of the patients showing a high expression of $\mathrm{hDlg}$ with that of patients showing a low expression of $\mathrm{hDlg}$. The Kaplan-Meier survival analysis and log-rank tests were performed in all patients (Fig. 2). A univariate analysis demonstrated the level of hDLG expression was significantly associated with MFS ( $p=0.0047$, Table II), DFS $(p=0.0062$, Table III), and OS ( $\mathrm{p}=0.0214$, Table IV). The MFH patients with lower expression of hDlg showed poorer MFS, DFS, and OS compared to those with higher expression of $\mathrm{hDlg}$. However, no significant association was observed between the expression level of $\mathrm{hDlg}$ and LRFS ( $\mathrm{p}=0.1098)$. The trunk MFHs showed poorer MFS compared with the extremity MFHs. There were no significant differences between MFS, DFS or OS, and other prognostic factors including the patient's age, gender, tumor size, and tumor depth in this series (Tables II, III and IV).

A multivariate analysis demonstrated the expression of $\mathrm{hDlg}$ to be the only independent prognostic factor for MFS and DFS ( $\mathrm{p}=0.0287$ and 0.0237 , respectively; Table V). The expression of $\mathrm{hDlg}$ was not an independent prognostic factor for OS. There were no significant differences in MDF or OS between initial MFH and recurrent MFH ( $\mathrm{p}=0.5128$ and 0.0606 , respectively; log-rank test).
A

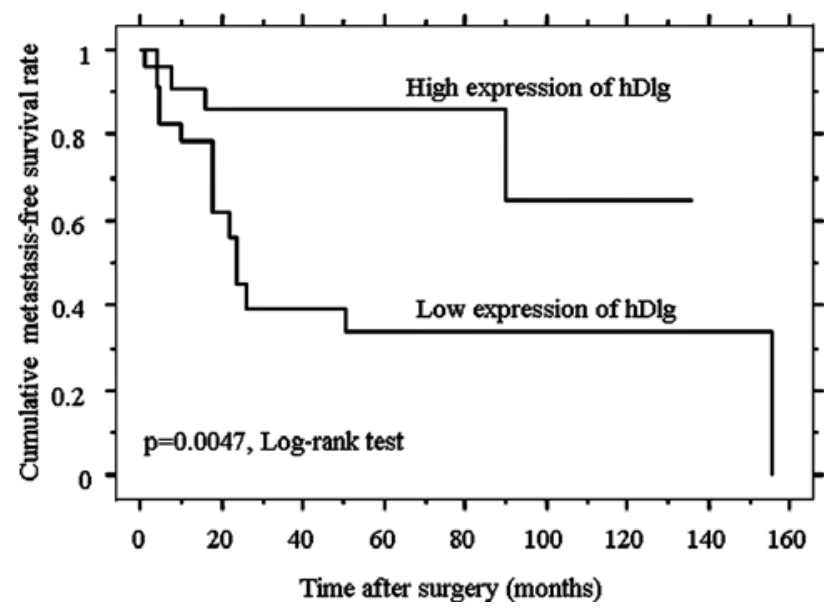

B

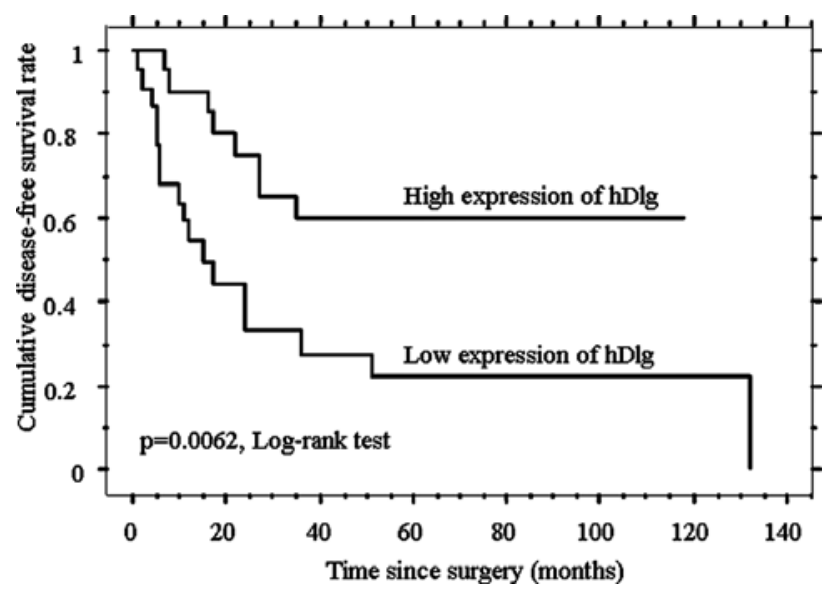

C

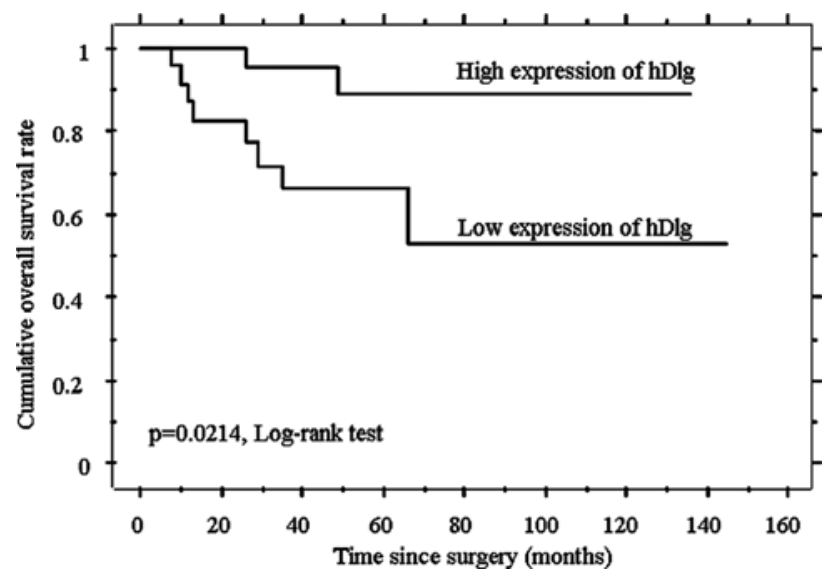

Figure 2. (A) Cumulative metastasis-free survival (MFS) of patients with a moderate or strong expression of $\mathrm{hDlg}$, compared to patients with a negative or weak expression in MFHs. (B) Cumulative disease-free survival (DFS) of patients with a moderate or strong expression of $\mathrm{hDlg}$, compared to patients with a negative or weak expression in MFHs. (C) The cumulative overall survival (OS) of patients with a moderate or strong expression of $\mathrm{hDlg}$, compared to patients with a negative or weak expression in MFHs. KaplanMeier curves confirmed that the metastasis-free survival rate, disease-free survival rate, and overall survival rates for patients with moderate or strong expression of $\mathrm{hDlg}$ were significantly reduced 
Table II. Univariate metastasis-free survival analysis in 46 patients with MFH.

\begin{tabular}{|c|c|c|c|}
\hline Factors & No. & $\begin{array}{c}5 \text {-Year metastasis- } \\
\text { free survival rate }(\%)\end{array}$ & P-value \\
\hline \multicolumn{4}{|l|}{$\begin{array}{l}\text { Patient's age } \\
\text { (years) }\end{array}$} \\
\hline$<60$ & 14 & 69.6 & 0.4332 \\
\hline$\geq 60$ & 32 & 57.0 & \\
\hline \multicolumn{4}{|l|}{ Gender } \\
\hline Male & 22 & 62.0 & 0.7230 \\
\hline Female & 24 & 59.7 & \\
\hline \multicolumn{4}{|l|}{ Size (cm) } \\
\hline$<5$ & 10 & 61.7 & 0.7298 \\
\hline$\geq 5$ & 36 & 57.1 & \\
\hline \multicolumn{4}{|l|}{ Depth } \\
\hline Superficial & 10 & 39.4 & 0.2276 \\
\hline Deep & 36 & 66.2 & \\
\hline \multicolumn{4}{|l|}{ Location } \\
\hline Trunk & 12 & 28.1 & 0.0035 \\
\hline Extremity & 34 & 73.2 & \\
\hline \multicolumn{4}{|l|}{ hDLG $1^{\mathrm{b}, \mathrm{c}}$} \\
\hline Low & 23 & 33.5 & 0.0047 \\
\hline High & 23 & 86.1 & \\
\hline
\end{tabular}

${ }^{a}$ Log-rank test. ${ }^{b} \mathrm{hDLG} 1$ human homologue of Drosophila discs large tumor suppressor protein. 'Low means negative/weak, and high means moderate/strong.

\section{Discussion}

In this study, we investigated whether hDlg protein expression has a prognostic impact on MFH. A univariate analysis demonstrated that the MFH patients with the lower expression of hDlg showed poorer MFS, DFS, and OS compared to those with higher expression of $\mathrm{hDlg}$. A multivariate analysis demonstrated the expression of hDlg was the only independent prognostic factor for MFS and DFS. Our results clearly indicate, for the first time, that reduced expression of $\mathrm{hDlg}$ was associated with a more aggressive behavior of tumor cells in $\mathrm{MFH}$.

MFH is the most common soft-tissue sarcoma (STS) diagnosed in adult patients, constituting as much as $34 \%$ of all STS (28). MFH often shows an aggressive clinical course. Despite adequate treatment, the prognosis remains poor. The 5-year LRFS, MFS and OS were reported to be $63-87 \%, 62-63 \%$ and $50-74 \%$, respectively (26-30). Biomarkers which can predict the high-risk patients are very important, because such biomarkers may be a useful indicator for determining whether adjuvant therapeutic modalities such as irradiation and chemotherapy should be performed. In MFH, the tumor size, tumor location,
Table III. Univariate disease-free survival analysis in 46 patients with MFH.

\begin{tabular}{lccc}
\hline Factors & No. & $\begin{array}{c}\text { 5-Year disease-free } \\
\text { survival rate (\%) }\end{array}$ & P-value \\
\hline $\begin{array}{l}\text { Patient's age } \\
\text { (years) }\end{array}$ & & & \\
$<60$ & 14 & 59.8 & 0.1735 \\
$\geq 60$ & 32 & 34.4 & \\
Gender & & & 0.3701 \\
Male & 22 & 48.7 & \\
Female & 24 & 36.7 & 0.3436 \\
Size (cm) & & & \\
$<5$ & 10 & 24.0 & 0.9312 \\
$\geq 5$ & 36 & 47.1 & \\
Depth & & & \\
Superficial & 10 & 40.5 & \\
Deep & 36 & 42.4 & \\
Location & & & \\
Trunk & 12 & 33.3 & \\
Extremity & 34 & 45.4 & \\
hDLG1 & & & \\
Low & & & \\
High & 23 & & \\
\hline
\end{tabular}

${ }^{a}$ Log-rank test. ${ }^{b} \mathrm{hDLG} 1$ human homologue of Drosophila discs large tumor suppressor protein. 'Low means negative/weak, and high means moderate/strong.

microscopic tumor necrosis and histologic grade have been shown to be important prognostic factors $(27,30,35,36)$. Some of these factors are incorporated into staging systems that form the basis for decision making regarding adjuvant therapy and follow-up. However, these prognostic factors do not always reliably predict the patient's outcome because of the presence of histologic heterogeneity which reflects the biologic behavior of MFH. Therefore, objective prognostic factors which more closely reflect the histological grading are required.

$\mathrm{hDlg}$ is a cell-junction localized protein that is a regulator of cell polarity and proliferation $(8,37)$. In epithelial cells, hDlg colocalizes with E-cadherin at sites of cell-cell interaction, where it is thought to have both structural and signaling roles in association with the cytoskeleton $(38,39)$. Reuver et al described that hDlg can be found in an E-cadherine/catenin adhesion complex and this interaction seems to be mediated by the attachment of hDlg to the cortical cytoskeleton (38). Cavatora et al (22) analyzed the intracellular and tissue distribution pattern of $\mathrm{hDlg}$ in normal cervical epithelium and cervical cancer with immunochemistry. Thereafter, they described that hDlg was localized in the basal, parabasal and intermediate layers, but absent in the upper layer which 
Table IV. Univariate overall survival analysis in 46 patients with MFH.

\begin{tabular}{|c|c|c|c|}
\hline Factors & No. & $\begin{array}{c}5 \text {-Year overall } \\
\text { survival rate }(\%)\end{array}$ & P-value \\
\hline \multicolumn{4}{|l|}{$\begin{array}{l}\text { Patient's age } \\
\text { (years) }\end{array}$} \\
\hline$<60$ & 14 & 90.0 & 0.0544 \\
\hline$\geq 60$ & 32 & 67.8 & \\
\hline \multicolumn{4}{|l|}{ Gender } \\
\hline Male & 22 & 64.8 & 0.3446 \\
\hline Female & 24 & 85.2 & \\
\hline \multicolumn{4}{|l|}{ Size (cm) } \\
\hline$<5$ & 10 & 77.1 & 0.8472 \\
\hline$\geq 5$ & 36 & 74.5 & \\
\hline \multicolumn{4}{|l|}{ Depth } \\
\hline Superficial & 10 & 74.1 & 0.1330 \\
\hline Deep & 36 & 75.6 & \\
\hline \multicolumn{4}{|l|}{ Location } \\
\hline Trunk & 12 & 59.3 & 0.421 \\
\hline Extremity & 34 & 75.8 & \\
\hline \multicolumn{4}{|l|}{ hDLG1 $1^{\mathrm{b}, \mathrm{c}}$} \\
\hline Low & 23 & 66.1 & 0.0214 \\
\hline High & 23 & 84.2 & \\
\hline
\end{tabular}

${ }^{a}$ Log-rank test. ${ }^{b} \mathrm{hDLG} 1$ human homologue of Drosophila discs large

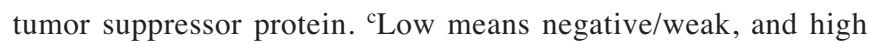
means moderate/strong.

consisted of differentiated cells in the normal cervical epithelium. This distribution pattern was similar to that of the adherences junction protein E-cadherin (40). In contrast, in the low-grade squamous intraepithelial lesion, the expression of $\mathrm{hDlg}$ was observed in the cytoplasmic area of the tumor cell with more intense staining, compared to normal tissue. In high-grade squamous intraepithelial lesion, cytoplasmic staining of hDlg was observed throughout the full thickness of the epithelium, which was composed of basal-type undifferentiated cells. Moreover, in the invasive cervical cancer, expression of Dlg was extremely weak or even absent. Lin et al (41) also evaluated the $\mathrm{hDlg}$ expression in cervical cancer and reported that in invasive cervical cancer, decreased hDlg expression was observed.

In the present study, in MFHs with relatively benign clinical course, the intensive staining of hDlg was observed in the cytoplasmic area of the tumor cells. In MFHs with a relatively poorer clinical outcome, weak or no staining was observed. Our observations of hDlg redistribution may be rationalized by the fact that both alterations of intracellular localization of $\mathrm{hDlg}$ and reduced expression of $\mathrm{hDlg}$ may play an important role in the biological behavior of the malignant cells, such as loss of polarity, high migration ability and invasive characteristics. The cytoplasmic accumulation of $\mathrm{hDlg}$ in patients with relatively good outcome may be causing the breakdown of cellular contacts between adjoining tumor cells, which do not have a critical impact on the prognosis. Moreover, the loss of hDlg may be considered a late stage marker in the carcinogenic process. Several mechanisms of the decreased expression of hDlg in patients with poor prognosis can be considered. The first possibility is that the MFHs without expression of hDlg may have a genetic point mutation or deletion in the $\mathrm{h} D l g$ gene locus, although there are no reports to date which indicate such a genetic aberration of the $\mathrm{h} D l g$ gene. Ishidate et al reported that the overexpression of $\mathrm{hDlg}$ suppresses cell proliferation by blocking cell cycle progression from the G0/G1 to S phase (18). hDlg also binds to the cytoplasmic domain of tumor necrosis factor $\alpha$ converting enzyme (TACE), which is the metalloprotease-disintegrin resoponsible for the ectodomain shedding of several proteins, including tumor necrosis factor $\alpha$ $(\mathrm{TNF} \alpha)(23)$. hDlg also binds via its PDZ domains to the carboxy-terminus of the adenomatous polyposis coli (APC)

Table V. Multivariate analysis of the metastasis-free survival and of the disease-free survival 46 patients with MFH.

\begin{tabular}{|c|c|c|c|c|c|c|}
\hline \multirow[b]{2}{*}{ Factors } & \multicolumn{3}{|c|}{ The metastasis-free survival } & \multicolumn{3}{|c|}{ The disease-free survival } \\
\hline & $\begin{array}{l}\text { Relative } \\
\text { risk }\end{array}$ & $\begin{array}{c}95 \% \text { Confidence } \\
\text { interval }\end{array}$ & P-value ${ }^{a}$ & $\begin{array}{l}\text { Relative } \\
\text { risk }\end{array}$ & $\begin{array}{c}95 \% \text { Confidence } \\
\text { interval }\end{array}$ & P-value \\
\hline Patient's age (years) $(<60$ vs. $\geq 60)$ & 0.405 & $0.096-1.717$ & 0.2200 & 0.401 & $0.112-1.428$ & 0.1584 \\
\hline Gender (male vs. female) & 1.013 & $0.359-2.854$ & 0.9812 & 1.665 & $0.681-4.071$ & 0.2635 \\
\hline Size $(\mathrm{cm})(<5$ vs. $\geq 5)$ & 2.057 & $0.563-7.515$ & 0.2750 & 1.795 & $0.635-5.075$ & 0.2699 \\
\hline Depth (superficial vs. deep) & 0.861 & $0.210-3.530$ & 0.8347 & 2.286 & $0.542-9.644$ & 0.2602 \\
\hline Primary vs. recurrent tumor & 0.596 & $0.158-2.252$ & 0.4452 & 1.006 & $0.337-3.003$ & 0.9908 \\
\hline Location (trunk vs. extremity) & 0.227 & $0.060-0.853$ & 0.0281 & 0.227 & $0.077-0.994$ & 0.0489 \\
\hline hDLG1 1,c (low vs. high) & 5.092 & $1.153-13.416$ & 0.0287 & 02.978 & $1.157-7.666$ & 0.0237 \\
\hline
\end{tabular}

${ }^{\mathrm{a} C o x}$ proportional hazards regression model. ${ }^{\mathrm{b}} \mathrm{hDLG} 1$ human homologue of Drosophila discs large tumor suppressor protein. ${ }^{\mathrm{c}}$ Low means negative/weak, and high means moderate/strong. 
tumor suppressor and forms an APC-hDlg complex, which is important for APC-mediated growth suppression $(15,18,37)$. Therefore, the functional abrogation of hDlg due to genetic aberration of $\mathrm{h} D l g$ gene may lead to uncontrollable cell proliferation and cell invasion. The second possibility is that viral infection may play a definitive role in development of MFH in some patients similar to patients with cervical cancer. It is now firmly established that high-risk human papilloma virus (HPV) plays a causal role in the development of cervical cancer. The E6 protein of high-risk HPV interacts with the PDZ domains of hDlg. Their E6 oncoproteins target hDlg for ubiquitin-mediated proteolysis and degradation of hDlg by the proteosome pathway $(16,22,23,43)$. Similar to HPV E6, both HTLV-1 Tax and Ad9 E4 ORF1 also bind Dlg through a consensus PDZ-binding motif located at their $\mathrm{C}$ terminus (16). Suzuki et al reported that Tax abrogates the cell cycle regulatory function of $\mathrm{hDlg}$ possibly through APC, leading to deregulation of growth of HTLV-1-infected T-cells (17). In MFH, viral protein such as HPV E6, HTLV-1 Tax and Ad9 E4 ORF1 may play a definitive role in carcinogenesis. The third possibility is that reduced expression of $\mathrm{hDlg}$ is generated only as a result of the disruption of the normal cell architecture due to an aberration of the other key molecules which control cell polarity and cell growth. Further investigations are therefore warranted.

In conclusion, immunohistologically, the expression of $\mathrm{hDlg}$ protein was negative in $19(41.3 \%)$ specimens, weak in $4(8.7 \%)$, moderate in $16(34.8 \%)$ and strong in $7(15.2 \%)$. The patients with negative or weak expression of hDlg showed a significantly poorer MFS and DFS in comparison to those with a moderate or strong expression based on the findings of both univariate and multivariate analyses. These results suggest that the reduced expression of $\mathrm{hDlg}$ is an independent prognostic marker for the MFH patients. Further investigations are necessary to clarify the mechanisms of a reduced expression of hDlg in MFHs with an aggressive clinical course.

\section{Acknowledgements}

The authors thank Miss Chiyuki Ueno and Mrs. Katsura Chiba for their assistance in preparing the clinical records.

\section{References}

1. Woods DF and Bryant PJ: The discs-large tumor suppressor gene of Drosophila encodes a guanylate kinase homolog localized at septate junctions. Cell 66: 451-464, 1991.

2. Bilder D, Li M and Perrimon N: Cooperative regulation of cell polarity and growth by Drosophila tumor suppressors. Science 289: 113-116, 2000.

3. Gregorc U, Ivanova S, Thomas M, Turk V, Banks L and Turk B: $\mathrm{hDLG} / \mathrm{SAP} 97$, a member of the MAGUK protein family, is a novel caspase target during cell-cell detachment in apoptosis. Biol Chem 386: 705-710, 2005.

4. Craven SE and Bredt DS: PDZ proteins organize synaptic signaling pathways. Cell 93: 495-498, 1998.

5. Kornau HC, Seeburg PH and Kennedy MB: Interaction of ion channels and receptors with PDZ domain proteins. Curr Opin Neurobiol 7: 368-373, 1997.

6. Pawson T and Scott JD: Signaling through scaffold, anchoring, and adaptor proteins. Science 278: 2075-2080, 1997.

7. Sheng $M$ and Wyszynski M: Ion channel targeting in neurons. Bioessays 19: 847-853, 1997.
8. Caruana G: Genetic studies define MAGUK proteins as regulators of epithelial cell polarity. Int J Dev Biol 46: 511-518, 2002.

9. Kim E, Niethammer M, Rothschild A, Jan YN and Sheng M: Clustering of Shaker-type $\mathrm{K}^{+}$channels by interaction with a family of membrane-associated guanylate kinases. Nature 378: 85-88, 1995.

10. Pawson T: $\mathrm{SH} 2$ and $\mathrm{SH} 3$ domains in signal transduction. Adv Cancer Res 64: 87-110, 1994.

11. Kim SK: Cell polarity: new partners for Cdc42 and Rac. Nat Cell Biol 2: E143-E145, 2000.

12. Satoh K, Yanai H, Senda T, Kohu K, Nakamura T, Okumura N, Matsumine A, Kobayashi S, Toyoshima K and Akiyama T: DAP-1, a novel protein that interacts with the guanylate kinaselike domains of hDLG and PSD-95. Genes Cells 2: 415-424, 1997.

13. Takeuchi M, Hata Y, Hirao K, Toyoda A, Irie M and Takai Y: SAPAPs. A family of PSD-95/SAP90-associated proteins localized at postsynaptic density. J Biol Chem 272: 11943-11951, 1997.

14. Hanada T, Lin L, Tibaldi EV, Reinherz EL and Chishti AH: GAKIN, a novel kinesin-like protein associates with the human homologue of the Drosophila discs large tumor suppressor in T lymphocytes. J Biol Chem 275: 28774-28784, 2000.

15. Matsumine A, Ogai A, Senda T, Okumura N, Satoh K, Baeg GH, Kawahara T, Kobayashi S, Okada M, Toyoshima K and Akiyama T: Binding of APC to the human homolog of the Drosophila discs large tumor suppressor protein. Science 272: 1020-1023, 1996

16. Kiyono T, Hiraiwa A, Fujita M, Hayashi Y, Akiyama T and Ishibashi M: Binding of high-risk human papillomavirus E6 oncoproteins to the human homologue of the Drosophila discs large tumor suppressor protein. Proc Natl Acad Sci USA 94: 11612-11616, 1997.

17. Suzuki T, Ohsugi Y, Uchida-Toita M, Akiyama T and Yoshida M: Tax oncoprotein of HTLV-1 binds to the human homologue of Drosophila discs large tumor suppressor protein, hDLG, and perturbs its function in cell growth control. Oncogene 18: 5967-5972, 1999.

18. Ishidate T, Matsumine A, Toyoshima $\mathrm{K}$ and Akiyama T: The APC-hDLG complex negatively regulates cell cycle progression from the G0/G1 to S phase. Oncogene 19: 365-372, 2000.

19. Humbert P, Russell S and Richardson H: Dlg, Scribble and Lgl in cell polarity, cell proliferation and cancer. Bioessays 25 : 542-553, 2003.

20. Bissell MJ and Radisky D: Putting tumours in context. Nat Rev Cancer 1: 46-54, 2001.

21. Thiery JP: Epithelial-mesenchymal transitions in tumour progression. Nat Rev Cancer 2: 442-454, 2002.

22. Cavatorta AL, Fumero G, Chouhy D, Aguirre R, Nocito AL, Giri AA, Banks L and Gardiol D: Differential expression of the human homologue of Drosophila discs large oncosuppressor in histologic samples from human papillomavirus-associated lesions as a marker for progression to malignancy. Int J Cancer 111: 373-380, 2004.

23. Zhang Y, Dasgupta J, Ma RZ, Banks L, Thomas M and Chen XS: Structures of a human papillomavirus (HPV) E6 polypeptide bound to MAGUK proteins: mechanisms of targeting tumor suppressors by a high-risk HPV oncoprotein. J Virol 81: 36183626, 2007.

24. Liu LX, Liu ZH, Jiang HC, Qu X, Zhang WH, Wu LF, Zhu AL, Wang XQ and $\mathrm{Wu} \mathrm{M}$ : Profiling of differentially expressed genes in human gastric carcinoma by cDNA expression array. World J Gastroenterol 8: 580-585, 2002.

25. Fuja TJ, Lin F, Osann KE and Bryant PJ: Somatic mutations and altered expression of the candidate tumor suppressors CSNK1 epsilon, DLG1, and EDD/hHYD in mammary ductal carcinoma. Cancer Res 64: 942-951, 2004.

26. Hsu HC, Huang EY and Wang CJ: Treatment results and prognostic factors in patients with malignant fibrous histiocytoma. Acta Oncol 43: 530-535, 2004.

27. Zagars GK, Mullen JR and Pollack A: Malignant fibrous histiocytoma: outcome and prognostic factors following conservation surgery and radiotherapy. Int J Radiat Oncol Biol Phys 34: 983-994, 1996

28. Le Doussal V, Coindre JM, Leroux A, Hacene K, Terrier P, Bui NB, Bonichon F, Collin F, Mandard AM and Contesso G: Prognostic factors for patients with localized primary malignant fibrous histiocytoma: a multicenter study of 216 patients with multivariate analysis. Cancer 77: 1823-1830, 1996. 
29. Belal A, Kandil A, Allam A, Khafaga Y, El-Husseiny G, ElEnbaby A, Memon M, Younge D, Moreau P, Gray A and Schultz H: Malignant fibrous histiocytoma: a retrospective study of 109 cases. Am J Clin Oncol 25: 16-22, 2002.

30. Gibbs JF, Huang PP, Lee RJ, McGrath B, Brooks J, McKinley B Driscoll D and Kraybill WG: Malignant fibrous histiocytoma: an institutional review. Cancer Invest 19: 23-27, 2001.

31. Fletcher CDM, Unni KK and Mertens FE (eds): Pathology and genetics of tumours of soft tissue and bone. In: World Health Organization Classification of Tumours. IARC, Lyon, 2002.

32. Birner P, Schindl M, Obermair A, Plank C, Breitenecker G and Oberhuber G: Overexpression of hypoxia-inducible factor $1 \alpha$ is a marker for unfavorable prognosis in early-stage invasive cervical cancer. Cancer Res 60: 4693-4696, 2000

33. Schindl M, Schoppmann SF, Samonigg H, Hausmaninger H, Kwasny W, Gnant M, Jakesz R, Kubista E, Birner P, Oberhuber G and Austrian Breast and Colorectal Cancer Study Group: Overexpression of hypoxia-inducible factor $1 \alpha$ is associated with an unfavorable prognosis in lymph node-positive breast cancer. Clin Cancer Res 8: 1831-1837, 2002.

34. Shintani K, Matsumine A, Kusuzaki K, Matsubara T, Satonaka H, Wakabayashi T, Hoki Y and Uchida A: Expression of hypoxiainducible factor (HIF)-1alpha as a biomarker of outcome in softtissue sarcomas. Virchows Arch 449: 673-681, 2006.

35. Engellau J, Anderson H, Rydholm A, Bauer HC, Hall KS, Gustafson P, Akerman M, Meis-Kindblom J, Alvegård TA, Nilbert $\mathrm{M}$ and Scandinavian Sarcoma Group: Time dependence of prognostic factors for patients with soft tissue sarcoma: a Scandinavian Sarcoma Group Study of 338 malignant fibrous histiocytomas. Cancer 100: 2233-2239, 2004.
36. Lahat G, Tuvin D, Wei C, Anaya DA, Bekele BN, Lazar AJ, Pisters PW, Lev D and Pollock RE: New perspectives for staging and prognosis in soft tissue sarcoma. Ann Surg Oncol 15: 2739-2748, 2008

37. Etienne-Manneville S, Manneville JB, Nicholls S, Ferenczi MA and Hall A: Cdc42 and Par6-PKCzeta regulate the spatially localized association of $\operatorname{Dlg} 1$ and APC to control cell polarization. J Cell Biol 170: 895-901, 2005.

38. Reuver SM and Garner CC: E-cadherin mediated cell adhesion recruits SAP97 into the cortical cytoskeleton. J Cell Sci 111: 1071-1080, 1998.

39. Ide N, Hata Y, Nishioka H, Hirao K, Yao I, Deguchi M, Mizoguchi A, Nishimori H, Tokino T, Nakamura Y and Takai Y: Localization of membrane-associated guanylate kinase (MAGI)-1/ BAI-associated protein (BAP) 1 at tight junctions of epithelial cells. Oncogene 18: 7810-7815, 1999.

40. Watson RA, Rollason TP, Reynolds GM, Murray PG, Banks L and Roberts S: Changes in expression of the human homologue of the Drosophila discs large tumour suppressor protein in highgrade premalignant cervical neoplasias. Carcinogenesis 23: 1791-1796, 2002

41. Lin HT, Steller MA, Aish L, Hanada T and Chishti AH: Differential expression of human Dlg in cervical intraepithelial neoplasias. Gynecol Oncol 93: 422-428, 2004.

42. Peiretti F, Deprez-Beauclair P, Bonardo B, Aubert H, JuhanVague I and Nalbone G: Identification of SAP97 as an intracellular binding partner of TACE. J Cell Sci 116: 1949-1957, 2003.

43. Mantovani F, Massimi P and Banks L: Proteasome-mediated regulation of the hDlg tumour suppressor protein. J Cell Sci 114: 4285-4292, 2001 . 